\title{
Lecturas de la literatura caribeña desde el Cono Sur (2005-2015)
}

\author{
Readings of Caribbean Literature from \\ the Southern Cone (2005-2015) \\ Leituras da literatura caribenha desde \\ - Cone Sul (2005-2015)
}

\section{Graciela Salto}

UNIVERSIDAD NACIONAL DE LA PAMPA, UNLPAM; CONSEJO NACIONAL DE INVESTIGACIONES CIENTÍFICAS Y TÉCNICAS, CONICET, ARGENTINA

Profesora Titular de Literatura Latinoamericana en la Universidad

Nacional de La Pampa e Investigadora Independiente en el Consejo

Nacional de Investigaciones Científicas y Técnicas (Conicet),

Argentina. Doctora en Letras por la Universidad de Buenos Aires.

Directora de la revista Anclajes (EISSN 1851-4669). Miembro Titular

de la Red Académica de Docencia e Investigación en Literatura y

Cultura Latinoamericana Katatay y de la Red Transcaribe. En 2010, editó el volumen Memorias del silencio: literaturas en el Caribe

y Centroamérica, publicado por el sello de Corregidor y, en 2012,

Ínsulas y poéticas: figuras literarias en el Caribe publicado por

la editorial Biblos. Correo electrónico: gsalto@hotmail.com 


\section{Resumen}

Un desarrollo excepcional de la lectura, la edición y los estudios críticos sobre las literaturas del Caribe se observa en la última década en el Cono Sur. Este proceso es el resultado de la formación de redes literarias y editoriales, pero también de los desplazamientos y exilios que signaron muchos de los intercambios sedimentados en la larga duración. En este artículo se describen algunos de los puntos nodales de este proceso de construcción de un campo de lecturas y de difusión de las literaturas del Caribe en el sur y se ofrece una bibliografía detallada de las publicaciones de la última década.

Palabras clave: literatura del Caribe; crítica literaria; América Latina; recepción literaria

\section{Abstract}

In the last decade, there has been an exceptional growth in the literary reception and the development of publishing and critical studies of the literatures of the Caribbean in the Southern Cone. This process results from the formation of literary and publishing networks, but also from displacements and exiles that marked many of the exchanges settled in the long term. This article examines some of the nodal points of this construction process of a field of reading and dissemination of Caribbean literature in the South and offers a detailed bibliography of the publications of the last decade.

Keywords: Caribbean literature; literary criticism; Latin America; literary reception

\section{Resumo}

Um desenvolvimento excepcional da leitura, a edição e os estudos críticos sobre as literaturas do Caribe observa-se na última década no Cone Sul. Este processo é o resultado da formação de redes literárias e editoriais, mas, também dos deslocamentos e exílios que marcaram muita troca sedimentada na longa duração. Neste artigo descrevem-se alguns dos pontos nodais deste processo de construção de um campo de leituras e difusão das literaturas do Caribe no sul e oferece-se uma bibliografia detalhada das publicações da última década.

Palavras-chave: literatura do

Caribe; crítica literária; América Latina; recepção literária

RECIBIDO: 22 DE FEBRERO DE 2017. ACEPTADO: 24 DE JUNIO DE 2017. DISPONIBLE EN LÍNEA: 8 DE AGOSTO DE 2018

\section{Cómo citar este artículo:}

Salto, Graciela. "Lecturas de la literatura caribeña desde el Cono Sur (2005-2015)". Cuadernos

de Literatura 22.43 (2018): 276-304. https://doi.org/10.11144/Javeriana.cl22-43.1lcc 
Más de doscientos estudios sobre las literaturas del Caribe se publicaron en la Argentina y en Chile en los últimos diez años. Se crearon colecciones editoriales para la difusión de la poesía, la narrativa y el ensayo caribeños y se organizaron grupos de trabajo y reuniones académicas de alcance internacional. No fue un movimiento repentino, sino la sedimentación de un proceso de larga duración, signado por los desplazamientos y los exilios, pero, ante todo, por las redes de lecturas y los nexos literarios y culturales que se fueron configurando entre una y otra región.

Los vínculos que estableció Juan María Gutiérrez en su América poética (1846-1847), donde aparecen ya poemas de los cubanos Gertrudis Gómez de Avellaneda o José María Heredia en una antología editada en el Río de la Plata, las crónicas de José Martí que se publicaron, unas décadas más tarde, en el diario La Nación de Buenos Aires (1882-1891), o el perdurable magisterio del dominicano Pedro Henríquez Ureña en la Argentina (1924-1946), muestran un itinerario de estas relaciones que se complejizaron tras el impacto cultural de la Revolución Cubana y lograron una renovada intensidad con los cambios geopolíticos y el auge de los estudios poscoloniales en las últimas décadas.

En este artículo se describen algunos puntos relevantes de este proceso y, sin afán de exhaustividad, se evalúa su incidencia en las formas de producción de conocimiento sobre las literaturas y las lenguas del Caribe en las instituciones universitarias y científicas de la Argentina y de Chile, donde se observa un interés particular por estas literaturas, con especial énfasis en las del área hispanohablante. El panorama que se traza intenta ofrecer algunas claves para la comprensión de este fenómeno, a pesar de las omisiones que surjan de la diversidad de los materiales y de las dimensiones generales del estudio.

\section{Un diseño relacional}

"Empezar no es partir de cero" (19) es la frase inicial del libro de Arcadio Díaz Quiñones publicado en 2006 por la Universidad Nacional de Quilmes en la Argentina. Ese libro sobre los intelectuales caribeños y la tradición condensó, de modo magistral, algunos de los saberes circulantes sobre el Caribe al mismo tiempo que abrió la posibilidad de explorarlos en ámbitos, como el de la historia intelectual que, hasta entonces, habían estado muy focalizados en los límites de las fronteras nacionales. Su repercusión fue alta: circuló entre historiadores, sociólogos, críticos literarios, y reubicó las culturas del Caribe en la agenda académica del sur. Su publicación coincidió con los cambios ocurridos tras la crisis financiera y política de la década anterior, que 
potenciaron una visión renovada del Latinoamericanismo y ampliaron las perspectivas comparadas entre las distintas regiones del continente. A su vez, en el ámbito más específico de la historiografía literaria, las hipótesis de Díaz Quiñones lograron un cruce productivo con los estudios sobre religación iniciados por Ángel Rama en la década de 1980, y actualizados, en los años siguientes, por los estudios de Ana Pizarro y de Susana Zanetti. ${ }^{1}$ De 2004 es el libro El sur y los trópicos, donde Pizarro señala, una década después de haber organizado su monumental historia de la literatura, América Latina: Palavra, Literatura e Cultura (1994), que nuestras diferencias se articulan mediante "patrones vinculantes, a veces rizomáticos, a veces en base a una matriz centralizada, pero perfilados en historias de diseño relacional" (24).

Este diseño, surgido de relaciones no siempre lineales, es el que sustentó a lo largo del siglo XX un conjunto de lecturas que establecieron nexos entre los imaginarios caribeños y las cartografías del sur. En la década de 1950, los ritmos afro de Nicolás Guillén y de Emilio Ballagas tuvieron amplísima difusión y algunas de sus obras se convirtieron en clásicos del repertorio literario escolar que se sumaron a la vigencia persistente de los poemas de Martí. A su vez, el auge de los movimientos poscoloniales y la impronta del surrealismo potenciaron la edición, en los años siguientes, de la obras de Alejo Carpentier y Reinaldo Arenas así como las de Aimé Césaire y Frantz Fanon. Desde 1956, fecha de la publicación inicial de El acoso por la editorial Losada de Buenos Aires, las novelas de Carpentier llegaron a tener tres y hasta cuatro ediciones diferentes, tanto en esta ciudad como en Santiago de Chile y, en algunos casos, en Montevideo. ${ }^{2}$ La circulación de sus obras solo podría compararse con las múltiples ediciones de los poemarios de Guillén

1 Véanse Zanetti "Religación" 5-8; "Modernidad y religación" 489-534).

2 Cfr. Carpentier (¿Ecué-Yamba-Ó! Historia Afrocubana [1933], Buenos Aires: Xanadú, 1968; Editorial Diez, 1974; El acoso. Buenos Aires: Losada, 1956; Jorge Álvarez, 1966; Montevideo: Biblioteca de Marcha, 1972; Calicanto, 1976; 1977; El reino de este mundo. Montevideo: Arca, 1965; Santiago de Chile: Editorial Universitaria, 1967; 1971; Montevideo: Arca, 1975; Buenos Aires: Librería del Colegio, 1975; Los pasos perdidos. Montevideo: Arca, 1966; Buenos Aires: Editorial Andina, 1969; Schapire, 1975; Ediciones del 80, 1985; Tres relatos: El camino de Santiago. Viaje a la semilla. Semejante a la noche. Montevideo: Arca, 1967; Buenos Aires: Galerna, 1967; 1968; El siglo de las luces. Buenos Aires: Galerna, 1967; 1980; Editorial Andina, 1969; Santiago de Chile: Editorial Orbe, 1969; Guerra del tiempo. Buenos Aires: Editorial Andina, 1969; Santiago de Chile: Editorial Orbe, 1969; Buenos Aires: Editorial Latina, 1975; Buenos Aires: Calicanto, 1977; Tientos y diferencias. Montevideo: Arca, 1967; 1970; Buenos Aires: Calicanto, 1976; Los convidados de plata. Montevideo: Sandino, 1972; Letra y Solfa. Selección, prólogo y notas de Alexis Márquez Rodríguez. Buenos Aires: Nemont, 1976; 
en la legendaria editorial Losada o con las de José Martí, en Kapelusz, Andrés Bello o Estrada. Guillén viajó a la Argentina en 1947 y fue entonces cuando entregó los manuscritos de El son entero a la editorial Pleamar. Viajes como este, las relaciones epistolares y el interés latinoamericanista de muchos editores sostuvieron, en gran medida, la publicación continua de obras caribeñas en el Cono Sur. ${ }^{3}$

La estadía en Buenos Aires del cubano Virgilio Piñera, entre 1946 y 1958, fue otro de los hitos de esta vinculación puesto que, desde el inicio, estableció una estrecha relación con los miembros de la revista Sur. Estos nexos incidieron en la difusión de su obra, pero también en la de los Origenistas, con quienes esta revista mantuvo intensos vínculos, estudiados por Nancy Calomarde (2010; 2015) y por Adriana Kanzepolsky (2004). En Buenos Aires se publicaron, en consecuencia, varias de las obras de Piñera. La carne de René fue editada por Siglo XX en 1952; los Cuentos fríos aparecieron en Losada en 1956; Dos viejos pánicos fue publicada en 1968 por el Centro Editor de América Latina y, en 1970, José Bianco, exsecretario de redacción de la revista Sur, prologó el volumen El que vino a salvarme, editado por Sudamericana. La figura y el legado de Piñera no dejaron de incrementarse en las décadas siguientes, de modo tal que, en los últimos años, se volvieron a publicar tres volúmenes de su obra, ${ }^{4}$ en estrecha articulación con el interés que suscita su escritura entre las nuevas generaciones. Su vigencia no opacó, sin embargo, la también perdurable valoración de la obra de José Lezama Lima, quien llegó a convertirse en "san Lezama", según la apreciación irónica de Martín Prieto, un reconocido crítico argentino de poesía. ${ }^{5}$ Lezama Lima no fue un autor tan profusamente editado en el sur, pero el halo de su figura trascendió la mera circulación de las obras ya que se fundó, primero, en las correspondencias estéticas y, en algunos casos, ideológicas entre los miembros de las revistas

Concierto barroco. Buenos Aires: Calicanto, 1977; El adjetivo y sus arrugas. Buenos Aires: Galerna, 1980; Ensayos selectos. Prólogo de Celina Manzoni. Buenos Aires: Corregidor, 2002).

También en Losada apareció la mayor parte de la obra del dominicano Manuel del Cabral, quien residió en Buenos Aires entre 1936 y 1944 y ocupó un lugar relevante en la vida intelectual de ese periodo.

4 Celina Manzoni editó y prologó, en 2009, una selección de sus cuentos para la editorial Corregidor mientras que la editorial Adriana Hidalgo publicó, en 2010, La carne, y la editorial Colihue presentó, en 2014, una nueva edición de Dos viejos pánicos y otros textos teatrales precedida por un estudio crítico de Nara Mansur.

5 La ironía consta en el artículo de Martín Prieto "Neobarrocos, objetivistas, epifánicos y realistas: nuevos apuntes para la historia de la nueva poesía argentina" (23-44). 
Orígenes y Sur y, más tarde, en la ampliación y renovación de lecturas producidas desde los inicios del periodo revolucionario. Por cierto, el triunfo de la Revolución Cubana profundizó, a nivel continental, el haz de relaciones descripto y la figura de Ernesto Che Guevara lo potenció en la Argentina. La publicación en Buenos Aires de Calibán (1973) de Roberto Fernández Retamar es uno de los ejemplos de esta recepción multidireccional del pensamiento revolucionario, ${ }^{6}$ que se mantuvo latente durante las dictaduras militares de la década siguiente, pero pudo reactivarse, bajo distinto signo, en las jóvenes democracias de los años ochenta y perdurar hasta la actualidad. De hecho, la versión completa y ampliada del célebre ensayo de Fernández Retamar, Todo Calibán, fue editado de nuevo en Buenos Aires en 2004, completando así un proceso editorial iniciado treinta años antes.

En otra línea, la editorial Sudamericana comenzó en 1974 la publicación en Buenos Aires de los ensayos de Severo Sarduy sobre el barroco que tuvo un eco inmediato en la teoría literaria y en la práctica poética locales. La aparición muy posterior de Caribe Transplatino. Poesia neobarroca cubana e rioplatense, organizado por Néstor Perlongher en Sâo Paulo (1991), puso en evidencia el impacto de aquellas tesis neobarrocas sobre los jóvenes poetas del Cono Sur a la vez que mostró el diseño relacional de esta poética que ha marcado, por afiliación u oposición, gran parte del campo literario de los últimos años, con numerosas ediciones y reediciones de los cubanos Lezama Lima, José Kozer y Damaris Calderón, entre otros. ${ }^{7}$

Este itinerario de relaciones, aunque brevísimo e incompleto, intenta ofrecer algunos indicios de que el interés por las literaturas y culturas del Caribe no es un fenómeno reciente ni esporádico en el sur. Está cimentado en procesos de larga duración que comenzaron a encontrar un cauce institucional en el década de 1990.

6 Dos libros publicados en Argentina, en la década pasada, analizaron estas redes: Fulguración del espacio. Letras e imaginario institucional de la Revolución Cubana (1960-1971) del puertorriqueño Juan Carlos Quintero Herencia (2002) y Entre la pluma y el fusil. Debates y dilemas del escritor revolucionario en América Latina (2003) de la argentina Claudia Gilman. Este último, en especial, tuvo una amplia recepción en Buenos Aires en la medida en que avivó discusiones preexistentes sobre los vínculos continentales de la intelectualidad cubana y la participación de los argentinos en la legitimación cultural de la revolución.

7 Para un estado de la cuestión en la Argentina, véase Ana Porrúa, "“Cosas que se están hablando': versiones sobre el neobarroco" (1-12). Con anterioridad, el ensayo de Daniel García Helder, "El neobarroco en la Argentina" (24-25). 


\section{La construcción de un campo}

En ese año, y por impulso del Centro de Estudios Martianos de La Habana, comenzaron a organizarse las Cátedras Libres José Martí en algunas universidades nacionales de la Argentina. Entre ellas, tuvo un papel muy activo la creada en la Universidad Nacional de La Plata que, desde su inicio, estuvo a cargo de Susana Zanetti, especialista apasionada por la poesía y la figura intelectual de Martí. ${ }^{8}$ En 1991, esa cátedra organizó un congreso internacional y, en 1998, un coloquio del mismo tipo, se publicaron actas de las reuniones y, en 1999, Zanetti compiló el libro Legados de fosé Martí en la crítica latinoamericana, donde se recopilan trabajos de quienes ya eran o habrían de ser algunas de sus discípulas más conocidas. ${ }^{9}$ También fue Zanetti quien alentó la lectura de otros autores contemporáneos, por ejemplo, las crónicas del puertorriqueño Edgardo Rodríguez Juliá, a quien dedicó estudios críticos e incluyó en sus programas de enseñanza universitaria. En su círculo académico, se realizaron varias tesis vinculadas con estos intereses que se hicieron visibles una década más tarde: Carolina Sancholuz publicó, en 2010, Mapa de una pasión caribeña. Lecturas sobre Edgardo Rodríguez fuliá, reelaboración de su tesis de doctorado. Y, en pocos años, se dieron a conocer otras dos tesis: la de Gabriela Tineo, En nuestra quimera ardiente y querida. Refundar la puertorriqueñidad en Luis Rafael Sánchez (2010) y la de Daniela Chazarreta Lecturas de la tradición en la poesía de fosé Lezama Lima (2012).

Este movimiento tuvo su apogeo varios años después de la asunción de los gobiernos democráticos en el Cono Sur y, en consecuencia, de la renovación y actualización de los estudios literarios en las universidades. En ese periodo, Ana Pizarro regresó a su país de origen, después de un exilio de varios años en los que trabajó en una línea historiográfica que promovió la pregunta por la ubicación del Caribe en la crítica literaria latinoamericana. ${ }^{10}$ En 2002, la Editorial de la Universidad de Santiago de Chile publicó su libro El archipiélago de fronteras externas: culturas del Caribe hoy que, en cierto modo, actúa como disparador de un número relevante de publicaciones de los años siguientes. En la introducción a este libro, Pizarro se centra en la

8 Un testimonio insoslayable de ese interés y dedicación a la obra martiana es la conversación con Susana Zanetti publicada por Miguel Leyva Ramos y Gabriela Tineo en 2003.

9 Sobre la creación y el funcionamiento de la cátedra de la Universidad Nacional de La Plata, véase el prólogo de Zanetti a esta publicación.

10 Pizarro había abordado estas cuestiones en un estudio seminal: "La noción de literatura latinoamericana y del Caribe como problema historiográfico" (132-140). 
movilidad y el desgarramiento intrínseco a la noción de lo caribeño y en la falta de límites precisos para una comunidad en perpetua transformación. Las "fronteras externas" delinean un espacio abierto, donde la interacción de múltiples lenguas y culturas exhibe una heterogeneidad que ha contribuido a diseñar, en gran medida, los estudios sobre el Caribe en el sur.

Pocos años después, en 2005, se creó el Grupo de Estudios Caribeños en el Instituto de Literatura Hispanoamericana de la Universidad de Buenos Aires por iniciativa de Celina Manzoni, cuyo libro Un dilema cubano. Nacionalismo y vanguardia ganó en el año 2000 el Premio Ensayo de Casa de las Américas. Este grupo se propuso fomentar y difundir el conocimiento de la literatura y la cultura del Caribe, en tanto región portadora de tradiciones y características propias, pero en estrecha articulación con el movimiento general del Latinoamericanismo. Además de su directora, lo integran Elsa Noya, Guadalupe Silva, María Fernanda Pampín, Ariela Schnirmajer y un conjunto de investigadores vinculados. Desde su creación, realizaron numerosas publicaciones, encuentros de trabajo y, en su ámbito, han dictado conferencias la mayoría de los escritores y estudiosos del Caribe que llegan hasta Buenos Aires. Con la orientación de Manzoni se llevó a cabo, también, una promisoria tarea de formación de recursos humanos. Ariela Schnirmajer y María Fernanda Pampín realizaron sus tesis de doctorado sobre las crónicas de Martí y Guadalupe Silva, sobre Paradiso de Lezama Lima. Elsa Noya, en cambio, se dedicó a los debates puertorriqueños de los últimos años del siglo XX mientras que Francisco Aiello, de la Universidad de Mar del Plata, realizó una tesis sobre la narrativa del Caribe francófono. En diciembre de 2015, se organizó en ese espacio la jornada de debate "Crítica literaria y cultural de América Latina", con el objetivo de analizar y discutir varias de las publicaciones sobre el Caribe producidas en los últimos años en el ámbito universitario de la Argentina.

Otro lugar donde se ha desarrollado un núcleo de investigadores sobre el Caribe es la Universidad Nacional de La Pampa. Allí se han generado estudios sobre literatura cubana y se organizaron varios encuentros académicos. Sonia Bertón culminó su doctorado, en 2010, con una tesis sobre La construcción de la subjetividad en la narrativa de Severo Sarduy; María Virginia González, en 2013, sobre Construcciones identitarias en la narrativa escrita por mujeres cubanas a fines del siglo XX y María Pía Bruno, en 2015, sobre Imágenes de la patria en el romancero cubano del siglo XIX. Se organizaron también dos libros que compilaron un estado de la cuestión de los estudios universitarios sobre el Caribe en el sur: Memorias del silencio: literaturas 
en el Caribe y Centroamérica, editado por Graciela Salto y publicado por Corregidor en 2010, y De ínsulas y poéticas: figuras literarias en el Caribe, publicado por Biblos en 2012. En ese año se organizó, también, el workshop "Lenguas y literaturas en el Caribe: avances en docencia e investigación", que contó con la participación de Myriam Coco de la Universidad de Bergen, Noruega, y de las especialistas argentinas Celina Manzoni, Teresa Basile, Florencio Bonfiglio y Francisco Aiello.

En articulación con los grupos anteriores, se encuentra un fuerte núcleo de institucionalización de los estudios caribeños en el seno de la Red Académica de Docencia e Investigación en el Área de la Literatura y Culturas Latinoamericanas Katatay, creada en 2005, por un convenio específico entre seis universidades nacionales de la Argentina (Comahue, Córdoba, La Plata, Mar del Plata, Rosario y Tucumán) a las que, en 2011, se sumó la de La Pampa. ${ }^{11}$ La red tuvo, desde su origen, un número importante de investigadores vinculados con los estudios del Caribe y esa es una de las razones que dio origen a la organización del Congreso Internacional El Caribe en sus Literaturas y Culturas. En el centenario del nacimiento de fosé Lezama Lima, que se celebró en la ciudad de Córdoba del 1 al 3 de septiembre de 2010. En esa oportunidad, participaron más de un centenar de investigadores locales y una decena de especialistas y escritores del exterior: Julio Ramos, Juan Carlos Quintero Herencia, Francisco Morán, Jorge Luis Arcos, Eduardo Lalo, Rafael Rojas, entre otros. En abril de 2015, se realizó la segunda instancia de este Congreso en la misma universidad, con una convocatoria similar y la participación de la escritora dominicana Aurora Arias y de los cubanos Marcial Gala y Alberto Guerra Naranjo. Entre los resultados de estas reuniones, se publicó en 2013 el volumen coordinado por Teresa Basile y Nancy Calomarde Lezama Lima: Orígenes, revolución y después... En forma paralela y articulada con lo anterior, desde 2005, se edita la revista de crítica literaria latinoamericana Katatay (ISSN 1669-3868), donde se han publicado numerosos dossiers sobre las literaturas del Caribe y estudios de reconocidos investigadores como Ana María Amar Sánchez, Francisco Morán y Juan Carlos Quintero Herencia, entre otros colaboradores.

En el marco de la red Katatay, también se realiza una activa formación de recursos humanos. Florencia Bonfiglio defendió en 2012 su tesis de doctorado Travesías de la religación en el siglo XX: apropiaciones de La Tempestad de Shakespeare en la literatura latinoamericana y caribeña que, un año antes,

11 Un detalle de las actividades de la red puede consultarse en http://www.redkatatay.org/sitio/ 
en 2011, obtuvo el primer premio en el Concurso Internacional de Ensayo sobre Calibán organizado por Casa de las Américas y, en 2014, Alejo López defendió la tesis Hacia una poética de la fruición y el desvío: la categoría de extraterritorialidad en la poesía niuyorriqueña de Tato Laviera. Por otra parte, en el Instituto Interdisciplinario de Estudios Latinoamericanos de la Universidad de Tucumán también se realizaron investigaciones sobre literatura cubana: Carmen Perilli publicó varios estudios sobre la obra de Leonardo Padura Fuentes, y Denise León defendió en 2013 su tesis sobre la poesía de José Kozer. Desde la Universidad de Rosario, Claudia Caisso coordinó y editó, en 2011 y 2013, dos volúmenes colectivos que incluyen estudios sobre literaturas del Caribe y, en los últimos años, dedicó varios trabajos a la obra de Derek Walcott. ${ }^{12}$

En la Universidad de Chile se organizó, en forma paralela, un núcleo muy productivo de investigadores, con énfasis sobre las literaturas caribeñas en lengua inglesa, francesa y los distintos creoles. Además del magisterio intelectual de Ana Pizarro, el seminario dictado por Ineke Phaf-Rheinberger en 2005 actuó como disparador de un interés específico por la dimensión africanista del Caribe, presente ya en el libro Memorias de la fragmentación que compiló los resultados de ese seminario. Los integrantes del Centro de Estudios Culturales Latinoamericanos de la Universidad de Chile desarrollan, desde entonces, varios proyectos de investigación y organizan las Jornadas Caribeñistas que, en 2014, llegaron a su sexta edición. Los resultados de estas actividades dieron lugar a varias publicaciones, entre ellas, los libros organizados por Elena Oliva, Lucía Stecher y Claudia Zapata sobre los legados respectivos de Aimé Césaire (2011) y de Frantz Fanon (2013); el volumen editado por Ana Pizarro y Carolina Benavente África/América: Literatura y Colonialidad (2014) y el libro de Elena Oliva sobre La negritud, el indianismo y sus intelectuales: Aimé Césaire y Fausto Reinaga (2014). La focalización sobre las diferencias étnicas y las tensiones inherentes al legado de la esclavitud es uno de los ejes más relevantes de las investigaciones realizadas en la Facultad de Filosofía y Humanidades de la Universidad de Chile, donde se lleva adelante, también, una promisoria tarea de formación de recursos humanos. En 2015, Elsa Maxwell defendió su tesis de doctorado sobre La escritura de mujeres, la esfera pública letrada y la autoría literaria femenina en el Caribe anglófono e hispano: los debates sobre la esclavitud y

12 Una visión general de la crítica latinoamericanista en la Argentina puede consultarse en Beatriz Colombi, "Escenarios de la crítica latinoamericanista: una visión desde Argentina" (213-226). 
su abolición en el siglo XIX, dirigida por Lucía Stecher, y otros tantos estudiantes están culminando sus tesis sobre literaturas caribeñas. En los últimos años, los vínculos académicos entre los equipos de ambos países avanzaron en una postergada complementariedad, a partir de encuentros, conferencias y simposios integrados por investigadores de uno y otro lado de los Andes.

\section{La construcción de un público}

En un proceso paralelo e interdependiente de los anteriores, la industria editorial volvió a apostarle, en los últimos años, a la difusión de autores del Caribe y retomó, de este modo, una tradición afincada en la ciudad de Buenos Aires, pero con notorios antecedentes también en Montevideo y en Santiago de Chile.

Entre las iniciativas más recientes, se destaca la creación de la colección Archipiélago Caribe que, con la dirección de María Fernanda Pampín, inauguró en 2011 la editorial Corregidor. Desde entonces, se publicaron siete volúmenes. Cuatro corresponden a dos autores de Puerto Rico: Eduardo Lalo (Simone, 2011, Premio Internacional de Novela Rómulo Gallegos en 2013), La inutilidad (2013), Los países invisibles (2014) y a Edgardo Rodríguez Juliá (La piscina, 2012). Un volumen corresponde a Un seguidor de Montaigne mira La Habana (2001/2014) del cubano José Antonio Ponte; otro, a la dominicana Aurora Arias (Emoticons, 2015) y el último, al cubano Marcial Gala (La Catedral de los negros, 2015).

Por cierto, Lalo, Ponte y Rodríguez Juliá, junto con los cubanos José Kozer y Lorenzo García Vega, son los autores caribeños con más ediciones y estudios críticos publicados en la Argentina en los últimos años. La editorial Beatriz Viterbo de Rosario concentró la difusión de los dos últimos. En 2009 publicó La nave del olvido, una antología de crónicas de Rodríguez Juliá. ${ }^{13}$ Unos años antes, en 2001, Ponte había iniciado su vínculo con esta editorial a partir del volumen El abrigo del aire. Ensayos sobre literatura cubana publicado, en forma conjunta, por Mónica Bernabé, Ponte y Marcela Zanín. La obra reúne una versión preliminar de "El libro perdido de los origenistas", que aparecería como libro en México al año siguiente, y otro ensayo de Ponte que da título al volumen "El abrigo del aire". Con un prólogo de Susana Zanetti, este libro constituye uno de los núcleos del proceso de valorización de la obra martiana y, al mismo tiempo, un punto de inflexión hacia las nuevas

13 En la misma colección, El Escribiente, la editorial había publicado unos años antes, el texto ficcional Por si nos da el tiempo (2002) de otro puertorriqueño, Julio Ramos, más conocido por su clásico Desencuentros de la modernidad en América Latina (1989). 
lecturas anticanónicas que tendrán su apogeo con la publicación, en la misma editorial, de La vigilia cubana: sobre Antonio fosé Ponte, un libro compilado por Teresa Basile en 2009. La aparición de este volumen y, al año siguiente, la edición de otros dos libros suyos en la misma editorial, Corazón de skitalietz y Las comidas profundas (2010), son indicios de una operación crítica tendiente a renovar el repertorio caribeño en el Cono Sur.

En forma paralela, dos editoriales de poesía editaron en Buenos Aires obras de José Kozer, de Lorenzo García Vega y del grupo Diáspora(s), mientras que varias editoriales chilenas (RIL, Las Dos Fridas, LOM y Cuarto Propio, entre otras) se ocuparon de la poesía de Damaris Calderón y de estudios sobre la poeta Nancy Morejón. En primer lugar, Tsé-Tsé, una editorial pequeña y prestigiosa, dirigida por el peruano Reynaldo Jiménez, incorporó a su flamante colección latinoamericana, llamada también "Archipiélago", dos libros de Kozer: Rosa cúbica (2002) y Carece de causa (2004). El cubano participó, en sintonía con esta presentación, en el Festival Fiestas Tseicas que se organizó el mismo año 2004 y compartió lecturas con Lorenzo García Vega, ${ }^{14}$ asiduo colaborador de la revista Tsé-Tsé desde sus primeros números. Allí también se publicó, en el número 13 de 2003, un reconocimiento al colectivo Diáspora(s) que incluyó una entrevista de Aníbal Cristobo al poeta Carlos Aguilera. Pocos años después, en 2006, otra editorial especializada en poesía, Bajo la Luna de Rosario, editó La garza sin sombras de Kozer, cuya obra había circulado ya, merced a dos libros presentados por la editorial Último Reino a fines de la década de 1980. A partir de 2007, Kozer comienza a ser editado, con éxito, en Chile, aunque mantiene contacto y viajes periódicos a ambos países. En el caso de Lorenzo García Vega, Bajo la Luna edita en 2005 No mueras sin laberinto, una compilación de su poesía escrita entre 1998 y 2004, y, dos años después, reedita su clásico ensayo autobiográfico Los años de Orígenes. Estas ediciones no pueden desgajarse del interés por la poesía neobarroca en el ámbito rioplatense y por el espacio editorial y

14 "En 2004, para celebrar los diez años de tsé tsé, en colaboración con la Estación Alógena de Buenos Aires, se realiza el festival Fiestas Tseicas, adonde participan poetas y colaboradores provenientes de diversos países. El festival cuenta con las lecturas y performances de, entre muchos otros, José Kozer y Lorenzo García Vega (Cuba/USA), y Soleida Ríos (Cuba)". Véase la presentación de la editorial en https://es-es.facebook.com/reynaldojimeneztsetse. Para una descripción de los avatares de la editorial,Felipe Cussen, «Tsé-tsé:lamosca quedespierta».DocumentosLingüísticosyLiterarios(2006) www.humanidades.uach.cl/documentos_linguisticos/document.php?id=1319 y la entrevista a ReynaldoJiménez en http://www.culturamas.es/blog/2011/03/27/entrevista-con-reynaldo-jimenez/. 
académico creado en torno al legado de Lezama, de Sarduy y de sus epígonos "neobarrosos", tal como se anticipó en las primeras páginas de este artículo.

La vigencia del barroco cubano en el sur se ha vista reforzada, también, por las ediciones de Colihue, una empresa de extensa trayectoria y amplio catálogo que ha editado una selección de la poesía de Fina García Marruz (2006), con prólogo de Susana Cella, y recientes antologías de poesía (2013) y de ensayos (2014) de José Lezama Lima, impulsados por Horacio González, director de la Biblioteca Nacional de Buenos Aires desde 2005 hasta 2015 y miembro activo de esa editorial. También allí se publicó una antología poética de Roberto Fernández Retamar (2012) y una reedición de piezas teatrales de Virgilio Piñera (2014) que supieron tener gran eco en Buenos Aires en la década de 1980.

En un circuito alternativo, la editorial "La Sofía cartonera" del Centro de Investigaciones de la Facultad de Filosofía y Humanidades de la Universidad Nacional de Córdoba ha lanzado la colección de literatura cubana Isla de cartón, con la dirección de la cubana residente en San Pablo, Idalia Morejón Arnaiz. En 2014, publicaron una Antología del Grupo Diásporas, con selección y notas de Morejón Arnaiz y otra antología de Omar Pérez titulada Ninguna Magia. En 2015, salió Violet Island y otro poemas, de María Reina Rodríguez y Visto desde el suelo de Juan Carlos Flores.

Por otra parte, la editorial Corregidor lleva adelante otras dos colecciones orientadas al público universitario: una, "Letras al sur del Río Bravo", dirigida por María Fernanda Pampín, y otra, "La inteligencia americana", dirigida por Beatriz Colombi. Se trata de ediciones seleccionadas de clásicos universitarios -Alejo Carpentier, Julián del Casal, José Martí, Virgilio Piñera- con valiosos estudios preliminares. Un párrafo aparte merecen, general, las reediciones de la obra de José Martí: diez libros publicados en diez años hablan de la vigencia de un clásico que cuenta con uno de los espectros más amplios de público, desde las lecturas escolarizadas hasta las motivaciones políticas de los sectores intelectuales.

En contraposición, son muy escasas las traducciones de textos del Caribe anglófono o francófono. En 2010, Florencio Bonfiglio publicó la selección de algunos textos de Kamau Brathwaite en la editorial Katatay y, en 2011, El 8vo. Loco presentó una edición bilingüe de Una tempestad de Aimé Césaire, otra obra muy difundida en los años setenta. En Chile, la editorial LOM publicó tres obras de Jamaica Kincaid (2007; 2009; 2011). En síntesis, una presencia escasa en el mercado editorial en relación con las múltiples publicaciones de autores cubanos y puertorriqueños. 


\section{Proyecciones}

El proceso de concentración del mercado editorial dificulta la publicación de obras que se presumen alejadas del circuito comercial y la fluidez de contactos abierta por los medios de comunicación masiva no ha tenido un correlato equivalente en la diversificación de los catálogos editoriales. A pesar de estas dificultades, se asiste en el sur a un despliegue promisorio de iniciativas que apuestan a renovar las lecturas canónicas de y sobre el Caribe y, al mismo tiempo, se observa la consolidación e institucionalización de un área de reflexión y análisis crítico sobre sus literaturas, lenguas y culturas en el ámbito universitario. Este movimiento ha enfatizado los vínculos con las áreas caribeñas de habla española, aunque se nota un interés creciente en las literaturas en otras lenguas. La imagen del archipiélago revitaliza así una tradición de relaciones que, como se explicó en los párrafos iniciales, lleva más de un siglo, pero que alcanza, ahora, horizontes inesperados. Los ritmos, bailes y fraseos del Caribe inundan las novelas de Washington Cucurto (seudónimo de Santiago Vega, Quilmes, 1970), creador de la editorial Eloísa Cartonera, pero por las costas del mar Caribe se mueven, también, los personajes de varias novelas de César Aira (Pringles, 1949), uno de los escritores argentinos más prolíficos y reconocidos de los últimos años. La crítica suele hablar de la "trilogía panameña" para referirse a la conjunción de sus libros Varamo (1999), El mago (2002) y La princesa primavera (2003) y, también, del Caribe venezolano, porque allí transcurre El congreso de literatura (1997). No son los únicos y, quizá, ni siquiera los más relevantes indicios del interés literario por el Caribe en el Cono Sur, pero sí una muestra de sus múltiples representaciones actuales.

\section{Obras citadas}

\section{Ediciones de obras literarias caribeñas en el Cono Sur (2005-2015)}

Arias, Aurora. Emoticons. Prólogo de Gabriela Tineo.

Buenos Aires: Corregidor, 2015. Impreso.

Brathwaite, Kamau. La unidad submarina. Selección, estudio preliminar y entrevista de Florencia Bonfiglio. Buenos Aires: Katatay, 2010. Impreso.

Calderón, Damaris. Las pulsaciones de la derrota.

Santiago de Chile: LOM, 2014. Impreso.

Calderón, Damaris. Parloteo de sombra. Santiago de Chile: LOM, 2009. Impreso.

Calderón, Damaris. Porque nos parecemos a las calaveras de Guadalupe Posada.

El Quisco: Ediciones Una Temporada en Isla Negra, 2013. Impreso. 
Césaire, Aimé. Una tempestad. Buenos Aires: El 8vo. Loco, 2011. Impreso.

Del Casal, Julián. Flores de invernadero. Prosa y poesía. Selección y prólogo de Ariela Schnirmajer. Notas de María Julia Olijnyk. Buenos Aires: Corregidor, 2012. Impreso.

Fernández Retamar, Roberto. Nosotros los sobrevivientes.

Santiago de Chile: LOM, 2010. Impreso.

Fernández Retamar, Roberto. Una salva de porvenir. Nueva antología

personal. Buenos Aires: Colihue, 2012. Impreso.

Gala, Marcial. La catedral de los negros. Buenos Aires: Corregidor, 2015. Impreso.

García Marruz, Fina. El peso de las cosas en la luz. Estudio preliminar, selección y prólogo de Susana Cella. Buenos Aires: Colihue, 2006. Impreso.

García Vega, Lorenzo. Los años de Orígenes. Buenos Aires: Bajo la Luna, 2007. Impreso.

García Vega, Lorenzo. No mueras sin laberinto. Poesía 1998-

2004. Buenos Aires: Bajo la Luna, 2005. Impreso.

Kincaid, Jamaica. Autobiografía de mi madre. Santiago de Chile: LOM, 2007. Impreso.

Kincaid, Jamaica. Lucy. Santiago de Chile: LOM, 2011. Impreso.

Kincaid, Jamaica. Mi hermano. Santiago de Chile: LOM, 2009. Impreso.

Kozer,José. De donde oscilan los seres en sus proporciones. Santiago de Chile: Ediciones del Temple, 2007. Impreso.

Kozer, José. La garza sin sombras. Buenos Aires: Bajo la Luna, 2006. Impreso.

Kozer,José. Lindes. Antología poética, prólogo y compilación de Pablo de Cuba y Soria. Santiago de Chile: LOM, 2014. Impreso.

Kozer, José. Mueca la muerte. Santiago de Chile: Norma, 2007. Impreso.

Kozer, José. Ocambo. Santiago de Chile: Animita Cartonera, 2007. Impreso.

Kozer, José. Partículas en expansión. Antología seleccionada y prologada por Arturo

Fontaine. Santiago de Chile: Consejo Nacional de Cultura y las Artes, 2014. Impreso.

Lalo, Eduardo. La inutilidad. Prólogo de Gabriela Tineo.

Buenos Aires: Corregidor, 2013. Impreso.

Lalo, Eduardo. Los países invisibles. Buenos Aires: Corregidor, 2014. Impreso

Lalo, Eduardo. Simone. Buenos Aires: Corregidor, 2011. Impreso.

Lezama Lima, José. Ensayos barrocos. Imagen y figuras en América Latina.

Prólogo de Horacio González. Buenos Aires: Colihue, 2014. Impreso.

Lezama Lima, José. Llamado deseoso. Antología poética.

Buenos Aires: Colihue, 2013. Impreso.

Martí,José. Amistad funesta. Buenos Aires: Vida-Global, 2011. Impreso.

Martí,José. Antología. Buenos Aires: EUDEBA, 2011. Impreso.

Martí,José. Escenas norteamericanas y otros textos. Selección, prólogo y notas de Ariela Schnirmajer. Buenos Aires: Corregidor, 2012. Impreso. 
Martí, José. Escritos sobre América, discursos y crónicas norteamericanas. Estudio preliminar de Beatriz Colombi. Buenos Aires: Capital Intelectual, 2010. Impreso.

Martí,José. Nuestra América. Buenos Aires: Vida-Global, 2011. Impreso.

Martí,José. Poemas selectos. Selección y prólogo de María Fernanda Pampín. Buenos Aires: Corregidor, 2009. Impreso.

Martí,José. Poesía Completa. Antología y prólogo de Susana Cella. Buenos Aires: Heliasta - Claridad, 2006. Impreso.

Padura, Leonardo. El viaje más largo. En busca de una cubanía extraviada. Buenos Aires: Capital Intelectual, 2013. Impreso.

Piñera, Virgilio. Cuentos selectos. Prólogo de Celina Manzoni. Buenos Aires: Corregidor, 2009. Impreso.

Piñera, Virgilio. Dos viejos pánicos y otros textos teatrales. Selección y estudio crítico Nara Mansur. Buenos Aires: Colihue, 2014. Impreso.

Piñera, Virgilio. La carne. Buenos Aires: Adriana Hidalgo, 2010. Impreso.

Ponte, Antonio José. Corazón de skitalietz. Rosario: Beatriz Viterbo, 2010. Impreso.

Ponte, Antonio José. Las comidas profundas. Rosario: Beatriz Viterbo, 2010. Impreso.

Ponte, Antonio José. Un seguidor de Montaigne mira La Habana. Prólogo de Teresa Basile. Buenos Aires: Corregidor, 2014. Impreso.

Rodríguez Juliá, Edgardo. La nave del olvido. Antología personal. Rosario: Beatriz Viterbo, 2009. Impreso.

Rodríguez Juliá, Edgardo. La piscina. Prólogo de Carolina Sancholuz. Buenos Aires: Corregidor, 2012. Impreso.

\section{Estudios críticos (2005-2015)}

\section{Libros}

Basile, Teresa (comp.). La vigilia cubana: sobre Antonio fosé Ponte. Rosario: Beatriz Viterbo, 2009. Impreso.

Basile, Teresa y Nancy Calomarde (comps.). Lezama Lima: Orígenes, revolución y después... Buenos Aires: Corregidor, 2013. Impreso.

Caisso, Claudia (coord.). Culturas literarias del Caribe. Córdoba: Alción; Universidad Nacional de Rosario, 2013. Impreso.

Caisso, Claudia. Estudios de cultura y literatura latinoamericana. Rosario: Universidad de Rosario, 2011. Impreso.

Calomarde, Nancy. El diálogo oblicuo: Orígenes y Sur, fragmentos de una escena de lectura latinoamericana (1944-1956). Córdoba: Alción, 2010. Impreso.

Calomarde, Nancy. El diálogo oblicuo: Orígenes y Sur, fragmentos de una escena de lectura latinoamericana (1944-1956). Leiden: Almenara, 2015. Impreso. 
Chazarreta, Daniela. Lecturas de la tradición en la poesía de fosé Lezama Lima. Quilmes: Caligrafías, 2012. Web. 3 de abril de 2015.

Cordones-Cook, Juanamaría. Soltando amarras y memorias: mundo y poesía en Nancy Morejón. Santiago de Chile: Cuarto Propio, 2009. Impreso.

Daroqui, María Julia. Escrituras heterofónicas. Narrativas caribeñas del siglo XX. Rosario: Beatriz Viterbo, 2005. Impreso.

Díaz Quiñones, Arcadio. Sobre los principios. Los intelectuales caribeños y la tradición. Bernal: Editorial de la Universidad Nacional de Quilmes, 2006. Impreso.

Estupiñán, Leandro. Lunes: un día de la Revolución Cubana.

Buenos Aires: Dunken, 2015. Impreso.

Grüner, Eduardo. La oscuridad y las luces. Capitalismo, cultura y revolución. Buenos Aires: Edhasa, 2010. Impreso.

León, Denise. El mundo es un hilo de nombres: sobre la poesía de fosé Kozer.

Tucumán: Instituto Interdisciplinario de Estudios Latinoamericanos, Universidad Nacional de Tucumán, 2013. Impreso.

Manzoni, Celina (ed.). Poéticas y políticas de la representación en la literatura latinoamericana. Buenos Aires: Corregidor, 2015. Impreso.

Marinone, Mónica y Gabriela Tineo (eds.). Viaje y relato en Latinoamérica. Buenos Aires: Katatay, 2010. Impreso.

Noya, Elsa. Canibalizar la biblioteca. Debates del campo literario y cultural puertorriqueño (1990-2002). Puerto Rico: editorial Callejón, 2015. Impreso.

Noya, Elsa. Leer la patria. Ensayos y reflexiones sobre escrituras puertorriqueñas. Córdoba: Alción Editora, 2005. Impreso.

Oliva, Elena. La negritud, el indianismo y sus intelectuales: Aimé Césaire y Fausto Reinaga. Santiago de Chile: Editorial Universitaria, 2014. Impreso.

Oliva, Elena, Lucía Stecher y Claudia Zapata. Aimé Césaire desde América Latina. Diálogos con el poeta de la negritud. Santiago de Chile: Facultad de Filosofía y Humanidades, Universidad de Chile, 2011. Impreso.

Oliva, Elena, Lucía Stecher y Claudia Zapata (eds.). Frantz Fanon desde América Latina. Lecturas contemporáneas de un pensador del siglo XX. Buenos Aires: Corregidor, 2013. Impreso.

Phaf-Rheinberger, Ineke. Memorias de la fragmentación: tierra de libertad y paisajes del Caribe. Berlín: wvb, 2005. Impreso.

Pizarro, Ana y Carolina Benavente (orgs.). África/América: Literatura y Colonialidad. Santiago: Fondo de Cultura Económica, 2014. Impreso.

Puppo, María Lucía. La música del agua. Poesía y referencia en la obra de Dulce María Loynaz. Buenos Aires: Biblos, 2006. Impreso. 
Salto, Graciela (ed.). De ínsulas y poéticas: figuras literarias en el Caribe. Buenos Aires: Biblos, 2012. Impreso.

Salto, Graciela (ed.). Memorias del silencio: literaturas en el Caribe y Centroamérica. Buenos Aires: Corregidor, 2010. Impreso.

Sancholuz, Carolina. Mapa de una pasión caribeña. Lecturas sobre Edgardo Rodríguez fuliá. Buenos Aires: Dunken, 2010. Impreso.

Silva, Guadalupe y María Fernanda Pampín (comps.). Literaturas caribeñas. Debates, reescrituras, tradiciones. Buenos Aires: Editorial de la Facultad de Filosofía y Letras, Universidad de Buenos Aires, 2015. Impreso.

Tineo, Gabriela. En nuestra quimera ardiente y querida. Refundar la puertorriqueñidad en Luis Rafael Sánchez. La Plata: Editorial de la Universidad Nacional de La Plata, 2010. Impreso.

Valero, Silvia. Mirar atrás - La importancia del pasado en los relatos de nación y negritud en la literatura a frocubana de entre siglos. Córdoba: Alción, 2014. Impreso.

Valero, Silvia y Alejandro Campos García (eds.). Identidades políticas en tiempos de afrodescendencia: auto-identificación, ancestralidad, visibilidad y derechos. Buenos Aires: Corregidor, 2015. Impreso.

\section{Tesis de doctorado ${ }^{15}$}

Aiello, Francisco. Revisión y reformulación de las construcciones identitarias en la narrativa del Caribe francófono: Chamoiseau, Condé, Laferrière (1980-2010). Tesis de doctorado. Mar del Plata: Universidad Nacional de Mar del Plata, 2012. Impreso.

Bertón, Sonia. La construcción de la subjetividad en la narrativa de Severo Sarduy. Tesis de Doctorado. La Plata: Universidad Nacional de La Plata, 2010. Web. 9 de junio de 2014.

Bonfiglio, Florencia. Travesías de la religación en el siglo XX: apropiaciones de La Tempestad de Shakespeare en la literatura latinoamericana y caribeña. Tesis de Doctorado. Buenos Aires: Universidad de Buenos Aires, 2012. Web. 12 de abril de 2015.

Bruno, María Pía. Imágenes de la patria en el romancero cubano del siglo XIX. Tesis de Doctorado. La Plata: Universidad Nacional de La Plata, 2015. Web. 2 de diciembre de 2016.

González, María Virginia. Construcciones identitarias en la narrativa escrita por mujeres cubanas a fines del siglo XX. Tesis de Doctorado. La Plata: Universidad Nacional de La Plata, 2013. Web. 5 de junio de 2015.

15 No se incluyen las tesis publicadas en formato libro ya que están consignadas en ese apartado. 
López, Alejo. Hacia una poética de la fruición y el desvío: la categoría de extraterritorialidad en la poesía niuyorriqueña de Tato Laviera. Tesis de Doctorado. La Plata: Universidad Nacional de La Plata, 2014. Web. 12 de diciembre de 2015.

Maxwell, Elsa. La escritura de mujeres, la esfera pública letrada y la autoría literaria femenina en el Caribe anglófono e hispano: los debates sobre la esclavitud y su abolición en el siglo XIX. Tesis de Doctorado. Santiago de Chile: Universidad de Chile, 2015. Impreso.

Silva, Guadalupe. La riqueza del vacío: el Paradiso ausente de fosé Lezama Lima.

Tesis de Doctorado. Buenos Aires: Universidad de Buenos Aires. 2005. Impreso.

\section{Dossiers}

Aiello, Francisco. "Dossier: Homenaje a Aimé Césaire (1913-2013)". Katatay. Revista crítica de literatura latinoamericana IX.11/12 (2014): 80-106. Impreso.

Aiello, Francisco. "Francofonía / Literatura Mundo: nuevas perspectivas para la literatura caribeña en lengua francesa". Katatay. Revista crítica de literatura latinoamericana V.7 (2009): 95-103. Impreso.

Amar Sánchez, Ana María. "La isla invisible. Escritura e intelectuales puertorriqueños de los 9o". Katatay. Revista crítica de literatura latinoamericana IV.6 (2008): 6-55. Impreso.

Basile, Teresa. "Dossier: La frontera Haití-República Dominicana: frontera, frontera". Katatay Revista crítica de literatura latinoamericana VIII.10 (2012): 120-131. Impreso.

Basile, Teresa. "Dossier Literatura sucia: Pedro Juan Gutiérrez". Katatay Revista crítica de literatura latinoamericana VI.8 (2010): 84-133. Impreso.

Basile, Teresa. "Dossier Nuevo ensayo cubano". Katatay Revista crítica de literatura latinoamericana I.1-2 (2005): 18-51. Impreso.

Basile, Teresa. "Dossier Portafolio de Julio Ramos". Katatay. Revista crítica de literatura latinoamericana IV.6 (2008): 56-63. Impreso.

Bonfiglio, Florencia. "Dossier: Asedios al archivo caribeño de la negritud: Aimé Césaire en el centenario de su nacimiento". Estudios. Revista de Investigaciones Literarias y Culturales 21.41 (enero-junio de 2013): 9-169. Web. 8 de julio de 2015.

Bonfiglio, Florencia. "Dossier sobre Kamau Brathwaite". Katatay. Revista crítica de literatura latinoamericana V.7 (septiembre de 2009): 37-83. Impreso.

López, Alejo. "Juan Flores: le memoria puertorriqueña". Katatay. Revista crítica de literatura latinoamericana VI.8 (noviembre de 2010): 148-160. Impreso.

Morán, Francisco. “"Dar la espalda de una vez a Martí y sus doctrinas': los 'Textos cautivos' de Juan Marinello sobre José Martî’'. Katatay. Revista crítica de literatura latinoamericana VII.9 (La Plata, noviembre de 2011): 109-131. Impreso. 
Pampín, María Fernanda. "Dossier: Los viajes de José Martî". Papel Máquina. Revista de Cultura 3.6 (2011). Web. 2 de abril de 2014.

Sancholuz, Carolina. "Dossier: Puerto Rico y el Caribe en perspectiva". Orbis Tertius XII.13 (2007). Web. 5 de mayo de 2015.

\section{Capítulos de libros ${ }^{16}$}

Aiello, Francisco. "Haití evocado / Haití revivido: memoria y discurso autobiográfico en dos textos de Dany Laferrière". Moradas narrativas: latinoamérica en el siglo XX. Ed. Aymará De Llano. Mar del Plata: Editorial Martín - Universidad Nacional de Mar del Plata, 2012. CD Rom.

Basile, Teresa. "Confines y sinfines de la Revolución Cubana. Reflexiones de un escritor impolítico: Antonio José Ponte". Cuba 50 años después: la revolución revis(it)ada. Eds. Andrea Gremels y Roland Spiller. Tubinga: Narr, 2010. 151-17o. Impreso.

Calomarde, Nancy. "Escrituras de la desparramazón cubana. El desarme del mito en la escritura de Antonio José Ponte". El canon en la narrativa contemporánea del Caribe y el Cono Sur. Eds. Rita De Maeseneer e Ilse Logie. Geneve: Librarie DROZ, 2014. 305-328. Impreso.

Calomarde, Nancy. "Heterodoxia y heterogeneidad en la poética de Orígenes". Gravitaciones en torno a la poética de Lezama Lima (La Habana, 1910-1976). Dirs. Laurence Breysse-Chanet e Ina Zalasar. París: Le manuscrit, 2010. 147-174. Impreso.

Calomarde, Nancy. "La mirada atroz". Virgilio Piñera tal cual. La Habana: Instituto Cubano del Libro, 2012. Impreso.

Calomarde, Nancy. "Orígenes en su tinta". Escrituras latinoamericanas: literatura, teoría y crítica en debate. Eds. Roxana Patiño y Nancy Calomarde. Córdoba: Alción, 2013. 53-81. Impreso.

Eichenbronner, Ana. "Ecos de Virgilio Piñera: la escritura como tema en las propuestas de los nuevos escritores cubanos". Poéticas y políticas de la representación en la literatura latinoamericana. Ed. Celina Manzoni. Buenos Aires: Corregidor, 2015. 79-96. Impreso.

Escobar, Mariela. "Representaciones del yo y autobiografía en Reinaldo Arenas".

Poéticas y políticas de la representación en la literatura latinoamericana.

Ed. Celina Manzoni. Buenos Aires: Corregidor, 2015. 63-78. Impreso.

Manzoni, Celina. "Nocturno cubano. La autobiografía de Reinaldo

Arenas". Del alba al anochecer. La escritura en Reinaldo Arenas. Coord.

María Teresa Miaja de la Peña. Frankfurt am Main - Madrid - México:

16 No se incluyen los capítulos incluidos en los libros citados. 
Iberoamericana Editorial Vervuert - Facultad de Filosofía y Letras, Universidad Nacional Autónoma de México, 2008. 145-163. Impreso. Noya, Elsa. "Caminando cuerpos y ciudades. Caribeñismo y escritura en la narrativa de Mayra Santos Febres y Eduardo Lalo". Errancia y escritura en la literatura latinoamericana. Comp. Celina Manzoni. Jaén: Editorial Alcalá, 2008. 75-93. Impreso.

Noya, Elsa. "El palpitar de la cultura. Los años noventa del campo cultural puertorriqueño". Escrituras en contrapunto. Estudios y debates para una historia crítica de la literatura puertorriqueña. Eds. Marta Aponte Alsina, Juan G. Gelpí y Malena Rodríguez Castro. San Juan: Universidad de Puerto Rico, 2015. 765-799. Impreso.

Noya, Elsa. "El peso de una isla en el ritmo el mundo. Poéticas de insularidad". Poéticas y políticas de la representación en la literatura latinoamericana. Ed. Celina Manzoni. Buenos Aires: Corregidor, 2015. 97-109. Impreso.

Noya, Elsa. "La contemporaneidad es un oxímoron". Violencia y silencio Narrativa latinoamericana contemporánea. Ed. Celina Manzoni. Buenos Aires: Corregidor, 2005. 239-260. Impreso.

Noya, Elsa. “"Quiero detenerme en la palabra...' A propósito del hueso duro de Gauguin". A Lomo de Tigre: homenaje a Luis Rafael Sánchez. Ed. Williams Mejías López. San Juan: Editorial de la Universidad de Puerto Rico, 2015. 167-174. Impreso.

Oliva, Elena. "El Estado ha traicionado a Haití: nación, Estado y revolución en el pensamiento de Jean Casimir". Haití de mis amores. Jean Casimir. Isla negra, Chile: Ambos Editores, 2013. 7-12. Impreso.

Oliva, Elena. "Identidad, migración y memoria en la literatura caribeña de Edwidge Danticat". América Latina en el nuevo milenio: procesos, crisis y perspectivas. Eds. Elena Oliva, Alondra Peirano, Elizabeth Prudant y Javiera Ruiz. Santiago de Chile: Centro de Estudios Culturales Latinoamericanos, Universidad de Chile, 2009. 109-129. Impreso.

Olivares, María Alejandra. "Bordes y desbordes del microrrelato: autonomía y dinámica contextual en Ana María Shua y Jamaica Kincaid". La pluma y el bisturí. Eds. Luisa Valenzuela Raúl Brasca y Sandra Bianchi. Buenos Aires: Catálogos, 2008. 317-328. Impreso.

Olivares, María Alejandra. "Jamaica Kincaid, microrrelato y novela: tradición y ruptura en la búsqueda identitaria". Asedios a una nueva categoría textual: El microrrelato. Eds. Andrés Cáceres Milnes y Eddie Morales Piña. Valparaíso: Facultad de Humanidades, Universidad de Playa Ancha, 2005. 141-152. Impreso. Pampín, María Fernanda. "Ensayos martianos. Modernidad y latinoamericanismo". Martí: Modernidad y latinoamericanismo. 
Ángel Rama. Selección de María Fernanda Pampín y Julio Ramos.

Caracas: Biblioteca Ayacucho, 2015. vii-xxx. Impreso.

Pampín, María Fernanda. "José Martí y la tradición. Redes intelectuales y literatura cubana en el siglo XIX". Poéticas y políticas de la representación en la literatura latinoamericana. Ed. Celina

Manzoni. Buenos Aires: Corregidor, 2015. 19-40. Impreso.

Pampín, María Fernanda. "Prólogo". José Martí. Poemas selectos.

Buenos Aires: Corregidor, 2009. 7-28. Impreso.

Perilli, Carmen. "Pedro Juan Gutiérrez: entre la carne y la sombra".

Sombras de autor. Buenos Aires: Corregidor, 2014. 43-53. Impreso.

Perilli, Carmen. "Sombras en una isla: José María Heredia y Ernst Hemingway".

Sombras de autor. Buenos Aires: Corregidor, 2014. 29-42. Impreso.

Pizarro, Ana. "Flujos en la construcción del discurso". El Caribe como paradigma. Eds. Ottmar Ette, Anne Kraume, Werner Mackenbach

y Gesine Müller. Berlín: Tranvía, 2012. 12-24. Impreso.

Rothe, Thomas. "Un sentido elegíaco cubano: La elegía como gesto transcultural en Carbones silvestres, de Nancy Morejón". Historias enredadas:

Representaciones asimétricas con vista al Atlántico. Ed. Ineke Phaf-Rheinberger. Berlín: Edition Tranvía - Verlag Walter Frey, 2011. 107-116. Impreso.

Sancholuz, Carolina. "Peregrinaje, exilio, errancia. Pedro Henríquez Ureña según Rafael Gutiérrez Girardot y Arcadio Díaz Quiñones". Redes intelectuales en América Latina. Los universos letrado y popular en la primera mitad del siglo XX.

Ed. Gloria Chicote. Rosario: Protohistoria ediciones, 2014. 133-146. Impreso.

Silva, Guadalupe. "Barroco y revolución. Identidad y modernidad en el ensayo americanista de Alejo Carpentier". Modernización e identidad. Tensiones de una disyuntiva constante en la historia y la literatura iberoamericana. Dir. Nidia Burgos. Bahía Blanca: Ediuns, 2006. 37-6o. Impreso.

Silva, Guadalupe. "Del insularismo al meta-archipiélago. El Caribe según Antonio Benítez Rojo". Errancia y escritura en la literatura latinoamericana. Ed. Celina Manzoni. Jaén: Ediciones Alcalá, 2009• 95-112. Impreso.

Silva, Guadalupe. "El poema, el gesto, la política. 'La isla en peso' de Virgilio Piñera". Poéticas y políticas de la representación en la literatura latinoamericana. Ed. Celina Manzoni. Buenos Aires: Corregidor, 2015. 111-134. Impreso. Silva, Guadalupe. " ¿Existe América Latina? Dos respuestas en dos tiempos: Volpi (2009), Fernández Retamar (1971)". Modernización / Identidad. Tensiones, disyuntivas y conciliaciones en la historia y la literatura Iberoamericana. Ed. Nidia Burgos. Bahía Blanca: Ediuns, 2011. 159-168. CDRom. 
Silva, Guadalupe. "La disputa del presente: Jorge Mañach, José Lezama Lima y el grupo Orígenes". Violencia y silencio. Literatura latinoamericana contemporánea.

Ed. Celina Manzoni. Buenos Aires: Corregidor, 2005. 193-214. Impreso.

Tineo, Gabriela. "Entre miradas en pugna, el Caribe". Senderos en el bosque de palabras. La literatura como espacio de interacción. (Latinoamérica, siglos XIX y XX). Ed. Mónica Scarano. Mar del Plata: Ediciones Suárez, 2006. 9-29. Impreso.

Tineo, Gabriela. "Fabulaciones del nosotros, fabulaciones del yo. Biografía nacional y autobiografía en Puertorriqueños de E. Rodríguez Juliá". Grabar lo que se desvanece. Narrativas de la memoria en América Latina. Eds. Mónica Marinone y Gabriela Tineo. Mar del Plata: Estanislao Balder, 2007. 47-71. Impreso.

Tineo, Gabriela. "Memorias desterradas. Memorias recuperadas". Escrituras y exilios en América Latina. Coord. Adriana Bocchino. Mar del Plata: Estanislao Balder, 2008. 67-102. Impreso.

Tineo, Gabriela. "Testimonio e imaginación: las crónicas de los 80 de Edgardo Rodríguez Juliá". Escrituras en contrapunto. Estudios y debates para una historia crítica de la literatura puertorriqueña. Eds. Marta Aponte Alsina, Juan G. Gelpí y Malena Rodríguez Castro. San Juan: Editorial de la Universidad de Puerto Rico, 2015• 317-340. Impreso.

\section{Artículos en revistas}

Aiello, Francisco. "Aimé Césaire ensayista: una lectura de Toussaint Louverture". Pilquen. Ciencias Sociales 17 (2013). Web. 12 de diciembre de 2015.

Aiello, Francisco. "Carpentier y Césaire: miradas sobre/desde Haitî". Espacios (nueva serie) VI.6 (2010): 26-37. Impreso.

Aiello, Francisco. "El Caribe francófono, América Latina, el mundo. Entrevista a Maximilien Laroche". Celehis 19.21 (2010): 367-385. Web. 1 de agosto de 2014.

Aiello, Francisco. "Elaboraciones de la cultura haitiana en Pays sans chapeau de Dany Laferrière". Literatura: Teoría, Historia, Crítica 15.2 (2013): 167-180. Impreso.

Aiello, Francisco. "Las culturas de América leídas desde el Caribe: Fernando Ortiz y Édouard Glissant". Texturas. Estudios Interdisciplinarios sobre el Discurso 10.11 (2011): 161-180. Impreso.

Aiello, Francisco. "Los usos de Toussaint Louverture: relecturas de la historia haitiana en la obra de Aimé Césaire". Estudios. Revista de Investigaciones Literarias y Culturales 41 (enero-junio de 2013): 93-113. Impreso.

Aiello, Francisco. "Moi, Tituba de Maryse Condé: reescribir la literatura de los hombres". Celehis 23 (2014): 11-29. Web. 2 de junio de 2015.

Bertón, Sonia. "Exiliado de sí mismo. Escritura, cuerpo y subjetividad en Pájaros de la playa". Anclajes X.10 (2006): 29-46. Impreso. 
Bonfiglio, Florencia. "Aimé Césaire y Tropiques: comienzos literarios en el Caribe francés". Literatura y Lingüística 25 (mayo de 2012): 17-37. Web. 20 de junio de 2014.

Bonfiglio, Florencia. "Correspondencias latinoamericanistas: una relectura de Calibán de Fernández Retamar". Celehis 28 (2014): 65-83. Web. 10 de diciembre de 2015.

Bonfiglio, Florencia. "El ensayo que se repite o el Caribe como lugar-común (Antonio Benítez Rojo, Édouard Glissant, Kamau Brathwaite)". Anclajes 18.2 (2014): 19-31. Impreso.

Bonfiglio, Florencia. "La máscara involuntaria de José Martí: la construcción del sujeto a través de la lectura de los Otros". Orbis Tertius. Revista de teoría y crítica literaria X.11 (2005): 97-108. Impreso.

Bonfiglio, Florencia. "Una tempestad de Aimé Césaire: una reescritura, varios pretextos". Estudios. Revista de Investigaciones Literarias y Culturales 21.41 (enero-junio de 2013): 137-169. Web. 10 de junio de 2014.

Bruno, María Pía. "Configuración de la patria y de las letras cubanas en el siglo XIX". Anclajes XIII (2009): 41-59. Impreso.

Caisso, Claudia. "El Caribe en sombras". Universum 25.2 (2010): 13-28. Impreso.

Caisso, Claudia. "Indigenización en el teatro de Derek Walcott". Amerika 13 (2015). Web. 21 de enero de 2016.

Caisso, Claudia. "José Lezama Lima y el neo-barroco americano". Confluenze. Rivista di Studi Iberoameriani 2.1 (2010): 31-39. Web. 11 de julio de 2014.

Caisso, Claudia. "La querella por la memoria en Édouard Glisant y Derek Walcott". Poligramas 37 (2013): 88-101. Impreso.

Caisso, Claudia. "Notas sobre el caribe en las poéticas del acriollamiento de Édouard Glissant y Edward Kamau Brathwaite". Perífrasis 4.8 (julio-diciembre de 2013): 104-119. Impreso.

Caisso, Claudia. "Viajeros en el Caribe de Derek Walcott". Meridional 4 (abril de 2015): 173-197. Web. 8 de junio de 2015.

Calomarde, Nancy. "Cómete este libro, Lezama". Diario de Cuba (12 de febrero de 2011). Web. 21 de junio de 2015.

Calomarde, Nancy. "El diálogo oblicuo. Reflexiones en torno al estudio de dos revistas culturales latinoamericanas". Mapocho 71 (2012): 87-102. Impreso.

Calomarde, Nancy. "Escritura y experiencia argentinas de Virgilio Piñera". Surco Sur de Arte y Literatura 3.5 (2013): 25-31. Web. 18 de julio de 2015.

Calomarde, Nancy. "La ficción sin límite". Tinkuy. Boletín de investigación y debate 13 (junio de 2010): 157-174. Web. 16 de julio de 2015.

Calomarde, Nancy. "La mirada atroz. Experiencias argentinas de Virgilio Piñera". La siempreviva. Renacimiento de Virgilio Piñera (2013): 38-43. Impreso. 
Calomarde, Nancy. "La ruta argentina de la escritura de Virgilio Piñera". Cuadernos del Sur 39 (2009): 53-72. Impreso.

Calomarde, Nancy. "Lecturas cruzadas: Orígenes y Sur, un debate im-posible". Escribas 6 (2011): 31-44. Impreso.

Calomarde, Nancy. "Notas desde y hacia la isla. Al margen de Rayuela y Libro de Manuel". RECIAL 4.4 (2013): 1-13. Web. 12 de julio de 2015.

Calomarde, Nancy. "Revolución y Colonización en el pensamiento crítico de Orígenes". Astrolabio 4 (2007). Web. 19 de enero de 2016.

Calomarde, Nancy. "Un barroco a lo argentino (mientras Bianco lee a Piñera)". Confluenze. Revista di Studi Iberoamericani 2.1 (2010): 82-98. Web. 14 de julio de 2015.

Calomarde, Nancy. "Una isla, todas las islas. Reflexiones en torno a la nueva narrativa cubana". Silabario 14 (noviembre de 2011): 85-102. Impreso.

Daroqui, María Julia. "Islas de caracoles viajeros". Katatay. Revista crítica de literatura latinoamericana II.3-4 (2006): 143-148. Impreso.

Foffani, Enrique. "Tato Laviera: el poeta sobre la cuerda floja". Katatay. Revista crítica de literatura latinoamericana 1.1-2 (2005): 82-105. Impreso.

González, María Virginia. "El decir de la hechura: una lectura de la estética piñeriana en dos cuentos fríos". Kamchatka. Revista de análisis cultural 1 (2013): 179-196. Web. 14 de febrero de 2015.

González, María Virginia. "Refugiarse en la escritura: un modo de configurar el exilio cubano". Caracol 7 (2014): 256-278. Web. 11 de marzo de 2015.

González, María Virginia. "Una aproximación a la construcción de la alteridad 'negra' y a los debates instaurados por las afrodescendientes en el feminismo latinoamericano". Anuario de la Facultad de Ciencias Humanas 10.2 (2013): 1-12. Impreso.

López, Alejo. "Ni de aquí ni de allá: la articulación entre poesía niuyorriqueña y tradición latinoamericana en la obra de Miguel Algarín y Tato Laviera". Caracol 8 (2014): 130-156. Web. 12 de enero de 2015.

López, Alejo. "Una bomba para gozar: la poesía de Tato Laviera". Hispamérica XLI.122 (2012): 109-113. Impreso.

Manzoni, Celina. "Poéticas de retorno. Las pesadillas del regreso en la cultura latinoamericana contemporánea". Celehis 24.29 (2015): 161-179. Web. 10 de enero de 2016.

Manzoni, Celina. "Violencia escrituraria, marginalidad y nuevas estéticas". Hipertexto. Online fournal 14 (verano 2011): 57-70. Web. 17 de abril de 2015.

Maxwell, Elsa. "La Literatura del Caribe Anglófono: Una revisión de la primera mitad del siglo XX". Acta Literaria 48.1 (2014): 101-116. Impreso. 
Maxwell, Elsa. "Representations of White Creole Women: The Characterization of Aunt Cora in Wide Sargasso Sea". White Rabbit: English Studies in Latin America 2 (2011): 1-15. Web. 5 de marzo de 2015.

Noya, Elsa. "Perspectivas académicas en la producción puertorriqueña de lo local". Zama (2 de abril de 2011): 81-104. Impreso.

Noya, Elsa. "Quiero detenerme en la palabra... A propósito del hueso de Gauguin". Orbis Tertius XII.13 (2007): 1-11. Impreso.

Noya, Elsa. "Retrato de familia con madre en el lecho". Nuestra América, Revista de Estudios sobre la Cultura latinoamericana 8 (enero-julio de 2010): 55-71. Impreso.

Noya, Elsa. "Una estética del exorcismo. Cuentística puertorriqueña actual". Revista de Estudios Hispánicos 33.1 (2006): 69-80. Impreso.

Oliva, Elena. "Detrás del antihaitianismo se oculta la negrofobia: conversación con el intelectual Silvio Torres-Saillant en Santiago de Chile". Meridional. Revista Chilena de Estudios Latinoamericanos 0.4 (2015): 199-226. Web. 2 de diciembre de 2015.

Oliva, Elena. "Discursos identitarios en América Latina: negritud e indianismo". Anuario de Postgrado 8 (2007-2008): 109-122. Impreso.

Oliva, Elena y Lucía Stecher. "Subjetividades, raza y memoria en Cosecha de huesos de Edwidge Danticat". Casa de las Américas 264 (2011): 106-120. Impreso.

Pampín, María Fernanda. "El regocijo hasta el extremo. La experiencia corporal en los Diarios de José Martî". Papel Máquina. Revista de cultura 3.6 (2011): 109-118. Web. 22 de junio de 2015.

Pampín, María Fernanda. "Elogio de la diversidad. Acerca del manifiesto de la creolidad de Jean Bernabé, Patrick Chamoiseau y Raphaël Confiant". Otras Modernidades 6.11 (2011): 109-120. Web. 5 de agosto de 2015.

Pampín, María Fernanda. "Ese don raro de asir la música y el espíritu de las lenguas. Los mecanismos implícitos en el proceso de traducción en la obra de José Martî”. Anclajes 16.2 (2012): 59-71. Impreso.

Pampín, María Fernanda. "Los Diarios de Martí y el hombre natural". Temas 52 (enero-marzo 2009): 105-114. Impreso.

Pampín, María Fernanda. "Visiones y re-visiones de Cuba: una estética de la violencia. Vista del amanecer en el trópico de Guillermo Cabrera Infante a partir de las ilustraciones de Amat". Zama 4 (2014): 39-52. Impreso.

Perilli, Carmen. "Mitologías de autor en la escritura de Leonardo Padura Fuentes. Entre Heredia y Hemingway". Revista Iberoamericana LXXIX.244-245 (julio-diciembre 2013): 989-999. Impreso.

Quintero Herencia, Juan Carlos. "Archipiélago puertorriqueño. Antología”. Katatay. Revista crítica de literatura latinoamericana II.3-4 (mayo de 2006): 87-142. Impreso. 
Salto, Graciela. "Ensayos sobre la lengua poética en Cuba". Revista Iberoamericana XXVIII.240 (julio-septiembre de 2012): 539-554. Impreso.

Sancholuz, Carolina. "Con la isla a cuestas: narrativa puertorriqueña en los Estados Unidos". Katatay. Revista crítica de literatura latinoamericana 6 (2008): 30-38. Impreso.

Sancholuz, Carolina. Desplazamiento y nuevos arraigos: Pedro Henríquez Ureña y la revista platense Valoraciones". Anales de Literatura Hispanoamericana 42 (diciembre 2013): 90-105. Impreso.

Sancholuz, Carolina. "Las ciudades y los ojos: miradas sobre San Juan de Puerto Rico". Arbor. Revista de Ciencia, Pensamiento y Cultura CLXXXVI.2 (septiembre-octubre de 2010): 191-205. Impreso.

Sancholuz, Carolina. "Puerto Rico en Nueva York: escritura, desplazamiento y sujetos migrantes en cuentos de Manuel Ramos Otero". Revista de Estudios Hispánicos 33 (2007): 117-138. Impreso.

Sancholuz, Carolina. "Topografía y memoria: lecturas sobre las crónicas El Cerro Maravilla y El cruce de la Bahía de Guánica y otras ternuras de la Medianía de Edgardo Rodríguez Juliá”. Actual investigación 55-56 (2004): 199-216. Impreso.

Sancholuz, Carolina. "Una poética de la muerte: sobre Invitación al polvo de Manuel Ramos Otero. Letral. Revista Electrónica de Estudios Transatlánticos de Literatura 6 (2011): 98-11. Web. 28 de junio de 2015.

Sanhueza, Marcelo. "Descolonización revolucionaria y construcción de una conciencia nacional en Los Condenados de la tierra de Frantz Fanon". Revista de Humanidades 31 (2015): 161-195. Impreso.

Silva, Guadalupe. "Alejo Carpentier, del negrismo a lo real maravilloso". Anclajes 19.1 (2015): 53-70. Web. 27 de diciembre de 2015.

Silva, Guadalupe. "Antonio José Ponte: el espacio como texto". Iberoamericana. América Latina, España, Portugal 2.5 (2014): 69-83. Impreso.

Silva, Guadalupe. "Avatares de un concepto. Notas sobre Lezama, Carpentier y el barroco americano". Lucero 15 (2004): 75-91. Impreso.

Silva, Guadalupe. "Cabrera Infante: con la ciudad en el cuerpo". Letr@viv@8.1(diciembre 2007): 115-130.Impreso.

Silva, Guadalupe. "De cara a la tradición: Borges y Lezama Lima". Moenia. Revista lucense de lingüistica \& literatura 8 (2002): 299-323. Impreso.

Silva, Guadalupe. "Del cuerpo a la palabra: acerca de la homosexualidad en Paradiso". Cuadernos Americanos 125.3 (julio-septiembre de 2008): 143-162. Impreso.

Silva, Guadalupe. "El mundo alucinante: construcción de la disidencia". Anclajes XV.1 y 2 (2011): 131-149. Impreso. 
Silva, Guadalupe. "Exilio y escritura en Gustavo Pérez Firmat". Confluenze. Rivista di studi iberoamericani I.2 (2009): 33-41. Web. 15 de mayo de 2015.

Silva, Guadalupe. "La novela y el relato de los orígenes (sobre Paradiso de José Lezama Lima)". Temas. Cultura, ideología, sociedad 59 (julio-setiembre de 2009): 165-173. Impreso.

Silva, Guadalupe. "Narración y sacrificio. Notas sobre El color del verano de Reinaldo Arenas". Literatura: teoría, historia y crítica 16.2 (2014): 173-182. Impreso.

Stecher, Antonio y Lucía Stecher. "Identidad y discursos multiculturales en los ensayos de Jamaica Kincaid". Revista de Estudios Filológicos 46 (2010): 137-155. Impreso.

Stecher, Antonio y Lucía Stecher. "Reflexiones sobre las identidades contemporáneas a partir de No Telephone to Heaven de Michelle Cliff". Estudios Filológicos 43 (septiembre de 2008): 191-206. Impreso.

Stecher, Lucía. "(A)filiaciones electivas: familia y relaciones de amistad interracial en Abeng de Michelle Cliff". Revista de Crítica Literaria Latinoamericana XXXIX.75 (2012): 465-481. Impreso.

Stecher, Lucía. "Diáspora, duelo y memoria en Mi hermano de Jamaica Kincaid". Revista chilena de literatura 78 (2011): 185-205. Impreso.

Stecher, Lucía. "Dos estallidos paralelos y un universo que se curva: encuentros y desencuentros entre el Caribe e Hispanoamérica". Casa de las Américas 277 (octubre-diciembre 2014): 120-130. Impreso.

Stecher, Lucía. "Entre 'Los placeres del exilio' y los descontentos de la migración: Lucy, novela de Jamaica Kincaid". Alpha 30 (2010): 181-195. Impreso.

Stecher, Lucía. "La escritura política de Michelle Cliff". Acta literaria 44 (2012): 73-89. Impreso.

Stecher, Lucía. "Reescrituras de la infancia en Annie fohn de Jamaica Kincaid". Griffo 23 (2011): 24-27. Impreso.

Stecher, Lucía. "Subjetividades, raza y memoria en Cosecha de huesos, de Edwidge Danticat". Casa de las Américas 51 (2011): 106-121. Impreso.

Stecher, Lucía. "Y la balsa va: historias de emigración y naufragio en la narrativa de Ana Lydia Vega y Edwidge Danticat". Estudios Avanzados Inter@ctivos 4.6 (2005).Web.28 de julio de 2015.

Stecher, Lucía y Elsa Maxwell. "Michelle Cliff's into the Interior and the Trope of the Solitary Female Immigrant". Callaloo 36.3 (2013): 811-821. Impreso.

Stecher, Lucía, Constanza Vergara y María Teresa Johansson.

"Migración y desplazamientos en Los Boys de Junot Díaz".

Taller de Letras 52 (2013): 119-134. Impreso. 
Tineo, Gabriela. "Auto-bio-grafía y Educación en el pensamiento crítico latinoamericano (Martí y Hostos)". Revista de Educación 4 (2012): 141-149. Web. 21 julio 2015.

Tineo, Gabriela. "Ciudades cimarronas. La utopía de la libertad en la narrativa de Edgardo Rodríguez Juliá”. Actual investigación 58.37 (2005): 41-58. Impreso.

Tineo, Gabriela. "'Como destino del corazón'. Derivas de un discurso apasionado". Estudios de Teoría Literaria. Revista Digital. Artes, Letras y Humanidades 2.4 (2013): 71-83. Web. 5 de junio de 2015.

Tineo, Gabriela. "De imágenes, identidades y territorios". Revista de Estudios Hispánicos 33.1 (2006): 177-191. Impreso.

Tineo, Gabriela. "Imágenes de entresiglos", Orbis Tertius XII.13 (2007): 1-14. Impreso.

Tineo, Gabriela. "Intimidades públicas". Hispamérica XLI.22 (2012): 101-108. Impreso.

Tineo, Gabriela. "Las grietas de la memoria. Antes que anochezca de Julián Schnabel". Letraceluloide. Revista Virtual de Cine y Literatura 2.4 (mayo de 2008). Web. 19 de enero de 2016.

Yaksic, María José. “Aportes de Pedro Henríquez Ureña a la historiografía literaria en Latinoamérica". Revista Istmo. Revista virtual de estudios literarios y culturales centroamericanos 24 (2012). Web. 12 de abril de 2014.

\section{Entrevistas}

Basile, Teresa. "Entrevista a Antonio José Ponte". Katatay. Revista crítica de literatura latinoamericana I.1-2 (junio de 2005): 28-36. Impreso.

Benavente Morales, Carolina (ed. lit.). "Ineke Phaf-Rheinberger (ed.). El lenguaje-nación y la poética del acriollamiento: Una conversación entre Kamau Brathwaite y Édouard Glissant". Literatura y lingüística 19 (2008): 311-329. Web. 10 de junio de 2015.

Sancholuz, Carolina. "Entrevista al escritor puertorriqueño Edgardo Rodríguez Juliá". Iberoamericana 28 (diciembre 2007): 168-173. Impreso.

Tineo, Gabriela. "Escribo para defender nuestro derecho a la tragedia'. Entrevista a Eduardo Lalo". Revista del Celehis 24 (2012): 215-241. Impreso.

Tineo, Gabriela. "Pero a mí que no me nieguen mi parcela'. Entrevista a Edgardo Rodríguez Juliá". Exilio y escritura en América Latina. Coord. Adriana Bocchino. Mar del Plata: Estanislao Balder, 2008. 241-264. Impreso.

Tineo, Gabriela y Víctor Conenna. "Escribo para reivindicar nuestro derecho a la tragedia'. Conversación con Eduardo Lalo". Noticias del diluvio. Textos latinoamericanos de las últimas décadas. Coords. Mónica Marinone y Gabriela Tineo. Mar del Plata: EUDEM, 2013. 295-319. Impreso. 